\title{
The Antioxidant Effects of Capparis Ovata and Deferasirox in Patients with Thalassemia Major
}

Handan Duman ${ }^{1}$, Duran Canatan ${ }^{1 *}$, Güchan Alanoglu ${ }^{2}$, Recep Sutçu ${ }^{3}$ and Tufan Nayır ${ }^{4}$

${ }^{1}$ Department of Pediatric Hematology, Suleyman Demirel University, Turkey

${ }^{2}$ Department of Adult Hematology, Suleyman Demirel University, Turkey

${ }^{3}$ Department of Biochemistry, Suleyman Demirel University, Turkey

${ }^{4}$ Department of Public Health. Suleyman Demirel University, Turkey

\begin{abstract}
Iron overload and auto-oxidation of unpaired globin chains is the main cause of oxidative stress in thalassemia We aimed to show the additive antioxidant effect of capparis RYDUD and deferasirox in thalassemic patients. A total number of 40 thalassemia major patient aged between 7-30 years, who have been taken regular red cell $15 \mathrm{cc} / \mathrm{kg} /$ month to maintain $\mathrm{Hb}>10 \mathrm{gr} / \mathrm{dl})$ and chelation $(30 \mathrm{mg} / \mathrm{kg} /$ day $\mathrm{ICL}-670)$ for one year are involved. They were divided into two groups as control and study group randomly. Both study and control groups were followed by regular transfusion and chelation therapy. In addition study group has been taken capparis marmalade at the breakfast with a dose of a dessert-spoon (12.5 gr) younger than 10 years and a soup-spoon ( $25 \mathrm{gr})$ older than 10 years for 6 months. Hematological and biochemical parameters, ferritin at every month and oxidative-antioxidant status (MDA, CAT, Gpx, SOD) were measured at the beginning and at the end of the study. Serum ferritin and MDA levels declined significiantly in both groups (for ferritin; control group $p=0.00$; study group $p=0.00$ ) during the study but a much more decrease occured at MDA levels in the capparis given group $(p=0.02)$. There was no statistically significant difference between the groups at the initial and last SOD CAT, GPX, SOD levels. Further more in the study group a significant decrease in liver function tests has been occured (AST $p=0.05, A L T p=$ 0.01). The high levels of MDA in iron overloaded thalassemic patients is the best marker of oxidative stres. Generally decreased iron burden was associated with decreased oxidant damage. In vitro it was shown that iron chelators such as deferoxamine and deferipron neutrolyse intraselluler free iron and inhibits oxidation. Our findings suggest that combination of capparis with deferasirox maybe have additive effect on decreasing the oxidative damage and hepatoxicity.
\end{abstract}

Keywords: Thalassemia; Antioxidants; Capparis ovata

\section{Introduction}

Iron overload is one of the contributing cause of oxidative stress in thalassemic patients. As iron excesses transferrin capacity a low molecular weight iron called non-transferrin bound iron (NTBI) and its portion called labil plasma iron (LPI) occurs and causes production of oxygen-free radicals resulting in depletion of protective antioxidants. Also auto-oxidation of globin chains and premature hemolysis of red cell enhances the oxidative damage at thalassemic patients [1-3]. Oxidative stress induces apoptosis, leakage of protones from mitochondria and increases oxygen depletion causing damage to cell and organelle membranes. The long term clinical consequences of this process are hearth failure, liver fibrosis or cirrhosis and endocrinopathies The balance between the prooxidant and antioxidant levels becomes impaired while a decrease occurs in levels of antioxidant enzymes, an increase occurs in levels of MDA which is a good marker of lipid peroxidation [4].

Treatment strategies of thalassemic patients are regular transfusion and chelation therapy to main aim is to reduce iron overload and NTBI. There are so many studies about thalassemia and the effects of antoxidants on thalassemia patients. In recent years use of specially plant origin antioxidants, such has fermented papaya preparation has been shown to reduce the oxidative stress and damage on several organs [3]. Silymarin, a flavonoid, acts as iron chelator and also increases intracellular glutathione content, suggesting to restore cellular antioxidant defences [5]. Oral vitamin E supplies an amelioration at rate of antioxidant/oxidant levels and inhibition at lipid peroxidation in patients with thalassemia [6].
Capparis, a member of Capparidacaeae family, is used in phytomedicine as anti-oxidative, hypolipidemic, anti-inflammatory and anti-hepatotoxic agent. Its the buds contain lipids, alcaloids, flavanoid and polyphenols. It is known that the antioxidant effect of capparis is formed the composition of flavanoids and polyphenols in its compund [7-10]. In a study done by Yadav et al it has been shown that capparis decidua extracts possess antihepatotoxic activity against alloxan induced hepatotoxicity and furthermore a decrease in oxidative stress has been observed [11]. Antihyperglycaemic and antioxidant effect of rutin, a polyphenolic flavonoid in normal and streptozotocin-induced diabetic Wistar rats studied. A decrease in fasting blood glucose level and an increase in insulin level observed. Additionally a decrease in lipid peroxidation products and an increase in both enzymatic and non enzymatic antioxidant levels observed [12].

It has been shown that iron chelator agents have antioxidant effect on thalassemic patients. After incubation of thalassemic red cell with deferiprone it has been observed that MDA levels decreased [13]. Walter et al. [14] have been compared the antioxidant effectiveness of

*Corresponding author: Duran Canatan, Department of Pediatric Hematology, Suleyman Demirel University, Turkey, E-mail: dcanatan@superonline.com

Received June 07, 2013; Accepted June 27, 2013; Published June 30, 2013

Citation: Duman H, Canatan D, Alanoglu G, Sutçu R, Nayır T (2013) The Antıoxidant Effects of Capparıs Ovata and Deferasırox in Patıents with Thalassemia Major. J Blood Disorders Transf 4:142. doi:10.4172/2155-9864.1000142

Copyright: @ 2013 Duman $\mathrm{H}$, et al. This is an open-access article distributed under the terms of the Creative Commons Attribution License, which permits unrestricted use, distribution, and reproduction in any medium, provided the original author and source are credited. 
deferasirox and desferrioxamine and found a decrease in MDA levels in both groups and a positive correlatation with serum ferritin levels and a reverse correlatation with vitamin and alpha-tocopherol levels.

Under the highlights of these findings we hypothese that an improvement in oxidative status of patients with thalassemia would be possible with the combination of antioxidant plant and new oral chelator deferasirox. In the present study, we aimed to investigate the antioxidant effects of capparis ovata and deferasirox in thalassemic patients.

\section{Material and Methods}

\section{Capparis}

Capparidaceae contains the following $(\mathrm{g} / \mathrm{mg} / \mathrm{mcg}$ per $100 \mathrm{gr})$ Dried: Protein $=21 \mathrm{~g}$. Fat $=1.6 \mathrm{~g}$. Calcium $=123 \mathrm{mg}$. $\mathrm{Fe}=6.8 \mathrm{mg}$. Beta carotene $=165 \mathrm{mcg}$ Vitamin $\mathrm{B} 1=.02 \mathrm{mg}$. Vitamin $\mathrm{B} 2=.03 \mathrm{mg}$. Niacin $=8.8 \mathrm{mg}$. Vitamin $\mathrm{C}=5 \mathrm{mg}$. Kcal $=341$; Cooked: Protein $=$ 5.4 g. Fat $=0.2$ g. Calcium $=33 \mathrm{mg} . \mathrm{Fe}=2.8 \mathrm{mg}$. Beta carotene $=25$ mcg. Vitamin B1 $=.01 \mathrm{mg}$. Kcal $=92$. Un- debittered: Protein (crude) $=29.3 \%$. Oil $=0.7 \%$. Ash $=3.5 \%$. Fibre $($ crude $)=2.7 \%$. Carbohydrate (soluble) $($ starch $)=39.5 \%$; (sugars): Sucrose $=4.3 \%$. D-glucose $=0.2 \%$. D-fructose $=0.7 \%$. Amino acids $\left(\mathrm{g}[16 \mathrm{~g} \mathrm{~N}]^{-1}\right)$ : Aspartic acid $=7.7 \mathrm{~g}$. Threonine $=1.7$ g. Serine $=2.3$ g. Glutamic acid $=9.0$ g. Proline $=6.5$ g. Glycine $=3.5 \mathrm{~g}$. Alanine $=3.2 \mathrm{~g}$. Valine $=4.5 \mathrm{~g}$. Cysteine (performic acid oxidation $)=1.3 \mathrm{~g}$. Methionine $($ performic acid oxidation $)=1.8$ g. Isolelucine $=2.9 \mathrm{~g}$. Leucine $=7.0 \mathrm{~g}$. Tyrosine $=2.3 \mathrm{~g}$. Histidine $=1.3$ g. Lysine $=1.5 \mathrm{~g}$. Arginine $=15.1 \mathrm{~g}$. Minerals: Sulphur $=2.20 \mathrm{mg} / \mathrm{kg}^{-1}$ (dry). Potassium $=0.15 \%^{-1}$ (dry). Magnesium $=0.10 \%$ (dry). Calcium $=0.14 \%$ (dry). $\mathrm{Na}=0.01 \%$ (dry). $\mathrm{K}=1.03 \mathrm{mg} / \mathrm{kg}^{-0}$ (dry). Zinc $=42$ $\mathrm{mg} / \mathrm{kg}^{-1}$ (dry). Iron $=10.5 \mathrm{mg} / \mathrm{kg}^{-1}$ (dry). Manganese $=17 \mathrm{mg} / \mathrm{kg}^{-1}$ (dry). Copper $=8 \mathrm{mg} / \mathrm{kg}^{-1}$ (dry) [15]. Capparis marmelade was prepared from dried capparis and presented to patients by company.

\section{Patients}

Randomized, double blind and prospective study was done at Suleyman Demirel University, Department of Pediatric Hematology. The study was reviewed and approved by the Ethical Committee of Suleyman Demirel University Faculty of Medicine. The study was carried out in accordance with the ethical standards laid down in the World Medical Association Declaration of Helsinki. A total number of 40 patients with thalassemia major aged between 7-30 years, who are on regular red cell transfusion protocol (Red cell: $15 \mathrm{cc} / \mathrm{kg} / \mathrm{month}$ to maintain $\mathrm{Hb}>9-10 \mathrm{gr} / \mathrm{dl}$ ) and chelation therapy since one year (Deferasirox: $20 \mathrm{mg} / \mathrm{kg} / \mathrm{day}$ ) were included in this study. They were divided in two groups as control and study group randomly. Study group had capparis marmelade before the breakfast with a dose of a dessert-spoon (12.5 gr) who is younger than 10 years and a soupspoon ( $25 \mathrm{gr}$ ) who are older than ten years for 6 months in addition to deferasirox therapy. Control group was only taken regular deferasirox therapy. In study group there were 13 girls and 7 boys. The mean age was $18.08 \pm 5.2$. In control group there were 12 girls and 8 boys and the mean age was $19.08 \pm 6.2$. Patients with hepatic or cardiac failure and diabetes mellitus were excluded from study.

\section{Methods}

We measured hematological and biochemical parameters, ferritin at every month and oxidative-antioxidant status (MDA, CAT, Gpx, SOD) at the beginning and at the end of the study. Blood samples were taken as late as possible, at least 3-4 weeks after the last transfusion. For hemogram and antioxidant levels $2 \mathrm{ml}$ venous blood with EDTA and for biochemical parameters and ferritin $4 \mathrm{ml}$ venous blood was taken to simple polystren tubes. Hemogram, biochemical parameters and ferritin levels were studied at the same day and the samples for the antioxidant study stored at $-80^{\circ} \mathrm{C}$ and analyzed by spectrophotometric method. MDA levels were evaluated with Drapper and Hadley's method [16], SOD levels with Wolliam's method [17], CAT with Aebi's method [18] and Gpx with Paglia and Valentine's method [19].

\section{Statistical Analysis}

We used Mann-Whitney $U$ test for comparing control and study group and Willcoxon test for comparing the levels before and after therapy with capparis. The values of $p<0.05$ were accepted as significiant.

\section{Results}

At the beginning of the study MDA levels were higher in the study group then the control group ( $\mathrm{p}=0.023)$ and after the use of capparis MDA levels decreased both in the study and control groups ( $\mathrm{p}=0.02$, 0.05 , respectively, (Table 1) and significance between two groups regressed. $(p=0.817)$. A significant decrease in SOD concentration in both of the groups was obtained but there was no statistically significant difference between the groups. $(\mathrm{p}=0.146)$ A minimal increase in $\mathrm{Gpx}(\mathrm{p}=0.511)$ and not statistically significant decrease in catalase concentration was found ( $\mathrm{p}=0.838$ ) (Table 2).

At the beginning of the study AST levels were $97.3 \pm 75.7$ and after 6 month use of capparis the levels were measured as $58.5 \pm 23.5$ and this decreament was statistically significiant. $(\mathrm{p}=0.05)$ At the control group AST levels were $73.4 \pm 48.4$ and after 6 month the levelswere $51.6 \pm 21.1$ and this decreament was not statistically significiant $(\mathrm{p}=0.08)$.

Baseline ALT levels were $129.0 \pm 123.3$ and after the use of capparis a significiant decrease also occured in study group $(\mathrm{p}=0.01)$ and there was no statistically significiant decreament in control group $(\mathrm{p}=0.12)$ (Table 3).

As shown in Table 4, at baseline ferritin levels were high both in control and study group and after 6 month usage of level ferritin level declined significiantly both in control and study group $(\mathrm{p}=0.00, \mathrm{p}=0.00$ respectively, (Table 4 ).

\section{Discussion}

Prematurely denaturated erythrocytes, increased iron absorption and iron accumulation due to transfusions causes inevitably enlargement of non-transferrin bound iron and labil plasma iron pool in thalassemic patients $[2,20]$. NTBI was found in patients whose transferrin saturation was higher than $45 \%$ and LPI at levels higher than $85 \%$. This proportion of iron generates reactive oxygen radicals by Fenton reaction causing peroxidative damage to cell and organelle membranes, in long term to cell death. Previous studies have demonstrated the increased oxidative injury and insufficiency in antioxidant cellular defence mechanisms in thalassemic patients. Also auto-oxidation of globin chains, intramedullary ineffective erythropoiesis and low levels of adult hemoglobin enhance the oxidative damage [21,22]. It is

\begin{tabular}{|l|l|l|l|}
\hline & MDA at the begining level & MDA at the ending level & $\mathbf{p}^{* *}$ \\
\hline control group & $118.08 \pm 41.4$ & $71.35 \pm 34.3$ & 0.05 \\
\hline study group & $160.46 \pm 62.5$ & $84.59 \pm 52.7$ & 0.02 \\
\hline $\mathbf{p}^{*}$ & 0.023 & 0.817 & \\
\hline
\end{tabular}

* Mann-Whitney $U$ ** Wilcoxon test

Table 1: MDA levels in patients with thalassemia major. 


\begin{tabular}{|c|c|c|c|c|c|c|c|c|c|}
\hline & $\begin{array}{c}\text { SOD at the } \\
\text { begining level }\end{array}$ & $\begin{array}{c}\text { SOD at the ending } \\
\text { level }\end{array}$ & $\mathbf{p}^{\star *}$ & $\begin{array}{c}\text { Catalase } \\
\text { at the begining level }\end{array}$ & $\begin{array}{c}\text { Catalase } \\
\text { At the ending level }\end{array}$ & $\mathbf{p}^{\star *}$ & \begin{tabular}{|c|} 
Gpx-at the \\
begining level
\end{tabular} & $\begin{array}{c}\text { Gpx- } \\
\text { At the ending level }\end{array}$ & $\mathbf{p}^{\star *}$ \\
\hline control & $2027.7 \pm 427.0$ & $1232.1 \pm 356.1$ & 0.00 & $423.7 \pm 318.1$ & $276.9 \pm 250.8$ & 0.278 & $59.0 \pm 12.4$ & $62.3 \pm 8.5$ & 0.184 \\
\hline study & $1858.3 \pm 370.2$ & $1053.1 \pm 267.3$ & 0.00 & $366.8 \pm 280.9$ & $240.2 \pm 172.0$ & 0.133 & $55.2 \pm 11.4$ & $60.1 \pm 15.4$ & 0.526 \\
\hline $\mathbf{p}^{*}$ & 0.177 & 0.146 & & 0.569 & 0.838 & & 0.298 & 0.511 & \\
\hline
\end{tabular}

* Mann-Whitney $U$ ** Wilcoxon test

Table 2: SOD, Catalase and GPX levels in patients with thalassemia major.

\begin{tabular}{|c|c|c|c|c|c|c|}
\hline & AST at the begining level & AST at the ending level & $\mathbf{p}^{\star \star}$ & ALT at the begining level & ALT at the ending level & $\mathbf{p}^{* *}$ \\
\hline control & $73.4 \pm 48.4$ & $51.6 \pm 21.1$ & 0.08 & $87.6 \pm 69.5$ & $56.5 \pm 30.6$ & 0.12 \\
\hline study & $97.3 \pm 75.7$ & $58.5 \pm 23.5$ & 0.05 & $129.0 \pm 123.3$ & $62.3 \pm 28.0$ & 0.01 \\
\hline $\mathbf{P}^{*}$ & 0.224 & 0.398 & & 0.174 & 0.461 & \\
\hline
\end{tabular}

* Mann-Whitney $U$ ** Wilcoxon test

Table 3: AST and ALT levels in patients with thalassemia major.

believed that oxidative stress aggrevates the symptoms of many diseases including hemolytic anemias as beta thalassemias [3].

Furthermore chelating excess iron using antioxidants to ameliorate the oxidative stres in thalassemics are the novel treatment approach for supportive therapy. Tesoriere et al. administered $600 \mathrm{mg} /$ day vit $\mathrm{E}$ to 15 thalassemia intermedia patient resulted in decrease at MDA levels and increase in vit E levels for 3 months [6]. There are so much trials investigating antioxidant effects of different plant flavonoids such as polyphenols, rutin and curcemin. It has been known that rutin has protective effect on cytosol and curcemin protects red cell membranes and tea polyphenols have protection effect on both membranes and cytosol [23]. Epigallocatechin gallate (EGCG) and epicatechin gallate (ECG) which are components of grean tea have the ability of iron binding and free radical scavenging activities as they also have decreation effect on the the level of NTBI at iron overloaded erythrocytes [24]. Ounjaijean et al. [25], showed a decreaa decretaion ement in iron levels of plasma and a destroy at formation of red cell ROS in rats challenged with iron. Another study in which fermented papaya preparation is used in thalassemic patients also showed an increase at glutathione content of red blood cells, platelets and polymorphonuclear leukocytes, and reduced ROS, membrane lipid peroxidation resulting in reduced sensitivity to hemolysis and phagocytosis by macrophages and improved PMN ability to generate oxidative burst [26].

Previous studies have shown that serum malonyldialdehyde (MDA) levels which is an end end product of lipid peroxidation, was higher in thalassemic patients than healty controls accompanied by depletion of antioxidant levels [27-29]. One study correlated serum MDA levels with ferritin values, suggesting high iron levels produces oxidative injury to cells [26]. Similarly in the present study increased levels of ferritin and MDA values was found in both of the groups at the beginning of the study showing our patients exposed to high iron overload condition and oxidative stress. After six month in at both groups serum ferritin levels decreased signficiantly (control $\mathrm{p}=0.00$, study $\mathrm{p}=0.00$ ) as they were under treatment of deferasirox. As ferritin levels decreased, oxidative stress decreased too but a more significiant improvement occured at MDA levelsin the at study group (control $\mathrm{p}=0.05$, study $\mathrm{p}=0.02$ ) indicating capparis restored the oxidative environment. It is known that capparis is a rich source of antioxidant phytochemicals such as flavonoids $[30,31]$. These flavonoids enter in to lipid bilayer of the cell membranes acting as anti-apoptotic or cytoprotective agent and protects the cell from death caused by reactive oxidative species [32].
This is the first report showing antioxidant effect of capparis ovata on patients with thalassemia. The results obtained from different studies on chelators also shows antioxidant capacity of them. It was found a decrease at lipid peroxidation by deferipron in thalassemic patients [13]. It has been showed a decreament in MDA levels with combination therapy of deferoxamine and $\mathrm{Fe}^{+} 2$ chelator DP (2,2-dipyridyl) in iron loaded human liver Hep-G2 cells [33]. A recent report compared antioxidant capacity of deferoxamine to deferasirox and resulted in equally effectiveness in decreasing MDA levels for 12 months and a positive correlation between MDA and ferritin and inverse correlation with vit $\mathrm{C}$ and alpha tocopherol [14]. Our findings are consistent with previous reports as we obtained a significiant decrease in MDA levels in both groups who are on deferasirox (control $p=0.05$, study $p=0.02$ ). This shows chelating free iron by deferasirox, not only decrease the transfused iron also counteracts the redox active iron at the membranes.

There are ambiguous results for antioxidant enzyme levels such as Glutathione-peroxidase, catalase and superoxide-dismutase in the literature. Some authors suggest increased activity due to compensation mechanism of increased oxidative stres [34,35] and the others suggest decreased activity $[13,36]$. In our study we found not significiant changes at three enzymes.

It is known that hepatic susceptibility in thalassemic patients is very common because of transfusion related HCV infections, hepatic siderosis, other infectious agents, iron induced glucose intoleration and chronic medications. There are reports about antihepatotoxic activity of capparis . p-Methoxy benzoic acid isolated from Capparis spinosa extract administered against carbontetrachloride and paracetamol induced hepatotoxicity in vivo and thioacetamide and galactosamine induced hepatotoxicity in isolated rat hepatocytes, proving antihepatotoxic activity of the plant. Consistent with literature our patients had high values of liver function tests at the beginning of the study. After 6 month a decrease occured in both groups but a significiant decrease obtained incapparis given group (AST $p=0.05$, ALT $p=0.01$ ) supporting its anti-hepatotoxic activity.

As conclusion, oxidative damage is seen because of the increased iron overload in thalassemic patients. The increase in MDA levels is the best marker of this damage. In the present study we obtained a decrease in the levels of MDA and liver function tests with using capparis. So it is possible that a combination of capparis with deferasirox (ICL670) may be usefull to improve the damage of oxidative stres and hepatotoxicity.

\section{Acknowledgements}

This study supported by a grant from Suleyman Demirel University, Unit of Scientific Research Projects, (Grant number 657). 


\begin{tabular}{|l|l|l|l|}
\hline & Ferritin at the begining level & Ferritin at the ending level & $\mathbf{p}^{* *}$ \\
\hline Control & $4406.8 \pm 2414.3$ & $3597.6 \pm 2163.8$ & 0.00 \\
\hline Study & $4654.2 \pm 1845.3$ & $3147.8 \pm 1245.4$ & 0.00 \\
\hline $\mathbf{P}^{*}$ & 0.227 & 0.957 & \\
\hline
\end{tabular}

* Mann-Whitney $U{ }^{* *}$ Wilcoxon test

Table 4: Ferritin levels in patients with thalassemia major.

\section{References}

1. Racmilewitz EA, Shirer S (2001) The pathophsiology of ß-thalassemia. In Disorders of Hemoglobin: Genetics, Pathophysiology and Clinical Management. Steinberg MH, Forget BG, Higgs DR, Nagel RL8eds). Cambridge Univesrity Press: Cambridge 233-251.

2. Rund D, Rachmilewitz E (2005) Beta-thalassemia. N Engl J Med 353: 11351146.

3. Fibach E, Rachmilewitz E (2008) The role of oxidative stress in hemolytic anemia. Curr Mol Med 8: 609-619.

4. Kukongviriyapan V, Somparn N, Senggunprai L, Prawan A, Kukongviriyapan $\mathrm{U}$, et al. (2008) Endothelial dysfunction and oxidant status in pediatric patients with hemoglobin E-beta thalassemia. Pediatr Cardiol 29: 130-135.

5. Alidoost F, Gharagozloo M, Bagherpour B, Jafarian A, Sajjadi SE, et al. (2006) Effects of silymarin on the proliferation and glutathione levels of peripheral blood mononuclear cells from ß-thalassemia major patients. International Immunopharmacology 6: 1305-1310.

6. Tesoriere L, D'Arpa D, Butera D, Allegra M, Renda D, et al. (2001) Ora supplements of vitamin $\mathrm{E}$ improve measures of oxidative stress in plasma and reduce oxidative damage to LDL and erythrocytes in beta-thalassemia intermedia patients. Free Radic Res 34: 529-540.

7. al-Said MS, Abdelsattar EA, Khalifa SI, el-Feraly FS (1988) Isolation and identification of an anti-inflammatory principle from Capparis spinosa. Pharmazie 43: 640-641.

8. Gadgoli C, Mishra SH (1999) Antihepatotoxic activity of p-methoxy benzoic acid from Capparis spinosa. J Ethnopharmacol 66: 187-192.

9. Goyal R, Grewal RB (2003) The influence of teent (Capparis decidua) on human plasma triglycerides, total lipids and phospholipids. Nutr Health 17: 71-76.

10. El-Ghorab A, Shibamoto T, Özcan M (2007) Chemical Composition and Antioxidant Activities of Buds and Leaves of Capers (Capparis ovata Desf. var. canescens) Cultivated in Turkey: Journal of Essential Oil Research.

11. Yadav P, Sarkar S, Bhatnagar D (1997) Action of capparis decidua against alloxan-induced oxidative stress and diabetes in rat tissues. Pharmacol Res 36: $221-228$

12. Kamalakkannan N, Prince PS (2006) Antihyperglycaemic and antioxidant effect of rutin, a polyphenolic flavonoid, in streptozotocin-induced diabetic wistar rats. Basic Clin Pharmacol Toxicol 98: 97-103.

13. Chakraborty D, Bhattacharyya M (2001) Antioxidant defense status of red blood cells of patients with beta-thalassemia and Ebeta-thalassemia. Clin Chim Acta 305: 123-129.

14. Walter $P$, Evans $P$, Giardina $P$ (2008) Control of Oxidant-Stress and Inflammation by Iron Chelators deferasirox (ICL670) or Deferoxamine in ß-Thalassemia: An Ancillary Study of the Novartis CICL670A0107 Trial Haematologica 93: 817825

15. Freedman R. Faminefoods-Capparidaceae. www.hort.purdue.edu/newcrop/ Faminefoods/ff indices/ff family_cd.html-7k cappariciadeae.htm

16. Draper HH, Hadley M (1990) Malondialdehyde determination as index of lipid peroxidation. Methods Enzymol 186: 421-431.
17. Woolliams JA, Wiener G, Anderson PH, McMurray CH (1983) Variation in the activities of glutathione peroxidase and superoxide dismutase and in the concentration of copper in the blood in various breed crosses of sheep. Res Vet Sci 34: 253-256.

18. Aebi H (1984) Catalase in vitro. Methods Enzymol 105: 121-126.

19. Paglia DE, Valentine WN (1967) Studies on the quantitative and qualitative characterization erythrocyte glutathione peroxidase. J Lab Clin Med 70: 158 169.

20. Loréal O, Gosriwatana I, Guyader D, Porter J, Brissot P, et al. (2000) Determination of non-transferrin-bound iron in genetic hemochromatosis using a new HPLC-based method. J Hepatol 32: 727-733.

21. Dhawan V, Kumar KhR, Marwaha RK, Ganguly NK (2005) Antioxidant status in children with homozygous thalassemia. Indian Pediatr 42: 1141-1145.

22. Naithani R, Chandra J, Bhattacharjee J, Verma P, Narayan S (2006) Peroxidative stress and antioxidant enzymes in children with beta-thalassemia major. Pediatr Blood Cancer 46: 780-785.

23. Kattamis C, Kattamis AC (2001) Oxidative stress disturbances in erythrocytes of beta-thalassemia. Pediatr Hematol Oncol 18: 85-88.

24. Thephinlap C, Ounjaijean S, Khansuwan U, Fucharoen S, Porter JB, et al (2007) Epigallocatechin-3-gallate and epicatechin-3-gallate from green tea decrease plasma non-transferrin bound iron and erythrocyte oxidative stress. Med Chem 3: 289-296.

25. Ounjaijean S, Thephinlap C, Khansuwan U, Phisalapong C, Fucharoen S, et al. (2008) Effect of green tea on iron status and oxidative stress in iron-loaded rats. Med Chem 4: 365-370.

26. Amer J, Goldfarb A, Rachmilewitz EA, Fibach E (2008) Fermented papaya preparation as redox regulator in blood cells of beta-thalassemic mice and patients. Phytother Res 22: 820-828.

27. Cighetti G, Duca L, Bortone L, Sala S, Nava I, et al. (2002) Oxidative status and malondialdehyde in beta-thalassaemia patients. Eur J Clin Invest 32 Supp 1: $55-60$.

28. Walter PB, Fung EB, Killilea DW, Jiang Q, Hudes M, et al. (2006) Oxidative stress and inflammation in iron-overloaded patients with beta-thalassaemia or sickle cell disease. Br J Haematol 135: 254-263.

29. Pavlova LE, Savov VM, Petkov HG, Charova IP (2007) Oxidative stress in patients with beta-thalassemia major. Prilozi 28: 145-154

30. Germanò MP, De Pasquale R, D'Angelo V, Catania S, Silvari V, et al. (2002) Evaluation of extracts and isolated fraction from Capparis spinosa $L$. buds as an antioxidant source. J Agric Food Chem 50: 1168-1171.

31. Bonina F, Puglia C, Ventura D, Aquino R, Tortora S, et al. (2002) In vitro antioxidant and in vivo photoprotective effects of a lyophilized extract of Capparis spinosa L buds. J Cosmet Sci 53: 321-335.

32. Panico AM, Cardile V, Garufi F, Puglia C, Bonina F, et al. (2005) Protective effect of Capparis spinosa on chondrocytes. Life Sci 77: 2479-2488.

33. Huang X, Dai J, Fournier J, Ali AM, Zhang Q, et al. (2002) Ferrous ion autoxidation and its chelation in iron-loaded human liver HepG2 cells. Free Radic Biol Med 32: 84-92.

34. Meral A, Tuncel P, Sürmen-Gür E, Ozbek R, Oztürk E et al. (2000) Lipid peroxidation and antioxidant status in beta-thalassemia. Pediatr Hematol Oncol 17: 687-693.

35. Kalpravidh RW, Wichit A, Siritanaratkul N, Fucharoen S (2005) Effect of coenzyme Q10 as an antioxidant in beta-thalassemia/Hb E patients. Biofactors 25: $225-234$.

36. Scott MD (2006) $\mathrm{H} 2 \mathrm{O} 2$ injury in beta thalassemic erythrocytes: protective role of catalase and the prooxidant effects of GSH. Free Radic Biol Med 40: 1264 1272.
Citation: Duman H, Canatan D, Alanoglu G, Sutçu R, Nayır T (2013) The Antıoxidant Effects of Capparıs Ovata and Deferasırox in Patıents with Thalassemia Major. J Blood Disorders Transf 4:142. doi:10.4172/2155 9864.1000142 